Article

\title{
Irrigation Timing as a Practice of Effective Weed Management in Established Alfalfa (Medicago sativa L.) Crop
}

\author{
Panagiotis Kanatas ${ }^{1, *(D)}$, Ioannis Gazoulis ${ }^{2}$ (D) and Ilias Travlos $^{2}$ (D) \\ 1 University of Patras, P.D. 407/80, 30200 Mesolonghi, Greece \\ 2 Laboratory of Agronomy, Department of Crop Science, Agricultural University of Athens, 75 Iera Odos Str., \\ 11855 Athens, Greece; giangazoulis@gmail.com \\ * Correspondence: pakanatas@gmail.com; Tel.: +30-6977568815
}

check for updates

Citation: Kanatas, P.; Gazoulis, I.; Travlos, I. Irrigation Timing as a Practice of Effective Weed Management in Established Alfalfa (Medicago sativa L.) Crop. Agronomy 2021, 11, 550. https://doi.org/ 10.3390/agronomy 11030550

Academic Editor: Dionisio Andújar

Received: 23 February 2021

Accepted: 11 March 2021

Published: 14 March 2021

Publisher's Note: MDPI stays neutral with regard to jurisdictional claims in published maps and institutional affiliations.

Copyright: (c) 2021 by the authors. Licensee MDPI, Basel, Switzerland. This article is an open access article distributed under the terms and conditions of the Creative Commons Attribution (CC BY) license (https:// creativecommons.org/licenses/by/ $4.0 /)$.

\begin{abstract}
Irrigation is an agronomic practice of major importance in alfalfa (Medicago sativa L), especially in the semiarid environments of Southern Europe. Field experimentation was conducted in Western Greece (2016-2018) to evaluate the effects of irrigation timing on weed presence, alfalfa yield performance, and forage quality. In a randomized complete block design (four replications), two cultivars ("Ypati 84" and "Hyliki") were the main plots, while three irrigation timings were the subplots (split-plot). The irrigation timings were IT-1, IT-2, and IT-3, denoting irrigation 1 week before harvest, 1 week after harvest, and 2 weeks after harvest, respectively. IT-1 reduced Solanum nigrum L. density by $54 \%$ and $79 \%$ as compared to IT-3 and IT-2, respectively. Chenopodium album L. density was the highest under IT-2. IT-3 resulted in 41\% lower Amaranthus retroflexus L. density in comparison to IT-2, while the lowest values were observed under IT-1. Stand density and stems.plant ${ }^{-1}$ varied $^{-}$ between years $(p \leq 0.05)$. Mass.stem ${ }^{-1}$ and alfalfa forage yield were affected by the irrigation timings $(p \leq 0.001)$. Total weed density and forage yield were negatively correlated in both the second $\left(R^{2}=87.013 \%\right)$ and the fourth $\left(R^{2}=82.691 \%\right)$ harvests. IT- 1 and IT-3 increased forage yield, leaf per stem ratio, and crude protein as compared to IT-2. Further research is required to utilize the use of cultural practices for weed management in perennial forages under different soil and climatic conditions.
\end{abstract}

Keywords: Medicago sativa L.; Chenopodium album L.; Solanum nigrum L.; Amaranthus retroflexus L.; forage yield; yield components; forage quality

\section{Introduction}

Alfalfa (Medicago sativa L.) is globally one of the most widely cultivated, high-yield, and high-quality forages [1], as well as the most widespread forage legume in Greece [2,3]. This perennial forage contributes to the soil's nitrogen equilibrium given the high nitrogen fixation rates, and it also improves soil structure since no soil disturbance is needed for several years after establishment [4]. Alfalfa is well adapted in a wide range of soil types across variable climatic conditions, and the stands are highly productive, especially from the year after establishment [5,6]. Alfalfa yield is described from three components, namely, stand density (plants. $\mathrm{m}^{-2}$ ), the number of stems per plant (stems.plant ${ }^{-1}$ ), and the mass produced per individual stem $\left(\mathrm{g} \cdot \mathrm{stem}^{-1}\right)$, while two important quality traits are the leaf per stem ratio and the crude protein content of the forage $[7,8]$.

Several cultural practices including irrigation regimes, fertilization, row spacing, seeding rates, and harvest frequency have been tested for their effects on the yield performance of alfalfa (e.g., forage yield and components of yield), as well as the quality attributes of the collected forage [9-14]. In warm climates and semiarid environments, frequent irrigation is necessary to achieve high yields $[15,16]$. Flooding in furrows, sprinkler irrigation, and the adoption of the subsurface drip irrigation systems are the most popular methods to irrigate alfalfa [14,17-19]. Sprinkler irrigation and especially the flooding methods are most commonly implemented in Greece; this trend is observed in many countries due to 
the low cost associated with such practices [20]. Several relative studies provided valuable information regarding the optimum irrigation rates and frequencies for this crop [15,21-24]. However, little research information is available in the literature regarding the effects of irrigation timing around a harvest on the weeds infesting a stand. Although alfalfa is generally considered to be a crop smothering weeds [25], weeds are adaptable to all environments and situations. In the absence of control methods, severe infestations might result in substantial yield losses for any crop [26]. Since they compete directly with the crop for natural resources, weeds have also the potential to reduce product quality, along with increasing the cost of the cultivation process [27].

There are several scientific reports attributing failure in the establishment of alfalfa to weed interference, highlighting the sensitivity of the crop to the presence of weeds until a dense canopy is formed [2,3,28-31]. Nonetheless, weed competition is also a threat for established alfalfa stands [32]. To address weed problems in established alfalfa, the application of synthetic herbicides has been the weed management practice mainly evaluated in the past [33-37]. There is a lack of information regarding the adoption of cultural practices for addressing weed problems in established alfalfa and preventing forage yield losses and quality downgrades. There is some evidence suggesting that irrigation timing can have a key role as such a cultural practice. In particular, Norris and Ayres [38] revealed that, if irrigation is delayed after harvest, the recovered canopy competes with yellow foxtail (Setaria glauca (L.) P. Beauv.) more effectively than the case where irrigation is applied in a short time after harvest. Alam and Rodgers [39] also suggested that irrigating the stand prior to harvest results in a rapid regrowth and enhances the competitiveness of the crop. On the contrary, irrigation right after harvest stimulates the emergence of weeds that can outcompete alfalfa since the canopy has not yet recovered from the clipping operation [38,39].

The objective of this study was to evaluate the effects of different irrigation timings on weed presence, alfalfa yield performance, and forage quality on different harvests carried out during the first and the second years after establishment. "Ypati 84" and "Hyliki" were the two genotypes selected for field experimentation. These are the most widespread cultivars of Greek origin given their similar rapid regrowth rates, high-yield potential, and high-quality attributes. The main hypothesis was that irrigating the stand either 1 week prior to harvest or 2 weeks after harvest could alleviate the crop from weed pressure and lead to higher yields. On the contrary, it was hypothesized that irrigating the stand in a short time after harvest would result in increased weed infestation levels, lower forage yields, and lower forage quality for both the evaluated cultivars.

\section{Materials and Methods}

\subsection{Site Description}

This field study was conducted from 2016 to 2018 in the region of Vonitsa located in Western Greece (latitude 20 $53^{\prime} 54^{\prime \prime}$ east (E), longitude $38^{\circ} 53^{\prime} 38^{\prime \prime}$ north (N)). The soil was a clay loam, whose physicochemical characteristics ( 0 to $15 \mathrm{~cm}$ depth increment) were clay $296 \mathrm{~g} \cdot \mathrm{kg}^{-1}$, silt $337 \mathrm{~g} \cdot \mathrm{kg}^{-1}$, sand $367 \mathrm{~g} \cdot \mathrm{kg}^{-1}$, organic matter $14.4 \mathrm{~g} \cdot \mathrm{kg}^{-1}, \mathrm{pH}\left(1: 2 \mathrm{H}_{2} \mathrm{O}\right) 7.6$, and $\mathrm{CaCO}_{3} 12 \mathrm{~g} \cdot \mathrm{kg}^{-1}$.

The climatic data obtained from 2016 to 2018 showed that the mean temperatures from May 2016 to July 2016 ranged between 20.3 and $29.5^{\circ} \mathrm{C}$. The maximum temperatures and the mean temperatures were higher for the summer months of 2017 than the corresponding values recorded for 2018 (Table 1). Regarding the monthly rainfall heights, they increased during the summer of 2018 in comparison to 2017. The same can be mentioned for May 2018, while the opposite trend was observed in April 2017. 
Table 1. Maximum monthly temperature, minimum monthly temperature, mean monthly temperature, and total monthly rainfall from 2016 to 2018.

\begin{tabular}{|c|c|c|c|c|c|c|c|c|c|c|c|c|}
\hline \multirow{2}{*}{$\begin{array}{l}\text { Weather } \\
\text { Parameter }\end{array}$} & \multicolumn{12}{|c|}{2016 (Establishment Year) } \\
\hline & January & February & March & April & May & June & July & August & September & October & November & December \\
\hline $\operatorname{Max} \operatorname{Temp}\left({ }^{\circ} \mathrm{C}\right)^{1}$ & 18.8 & 23.3 & 23.6 & 30.6 & 31.2 & 39.2 & 37.8 & 37.3 & 33.8 & 29.1 & 14.0 & 16.9 \\
\hline Min Temp $\left({ }^{\circ} \mathrm{C}\right)$ & -0.2 & 2.6 & 4.7 & 7.4 & 10.0 & 15.7 & 28.3 & 19.2 & 14.4 & 10.7 & 23.6 & -0.1 \\
\hline Mean Temp $\left({ }^{\circ} \mathrm{C}\right)$ & 9.9 & 13.4 & 12.4 & 18.1 & 19.2 & 25.3 & 18.5 & 27.7 & 22.4 & 18.5 & 4.0 & 8.2 \\
\hline Rainfall (mm) & 145.6 & 74.2 & 191.0 & 21.6 & 16.4 & 9.4 & 31.8 & 3.4 & 108.2 & 151.4 & 231.4 & 4.4 \\
\hline \multirow{2}{*}{$\begin{array}{l}\text { Weather } \\
\text { Parameter }\end{array}$} & \multicolumn{12}{|c|}{2017 (First Experimental Year) } \\
\hline & January & February & March & April & May & June & July & August & September & October & November & December \\
\hline $\operatorname{Max} \operatorname{Temp}\left({ }^{\circ} \mathrm{C}\right)$ & 14.1 & 21.4 & 26.9 & 29.1 & 31.9 & 40.2 & 42.3 & 39.3 & 36.6 & 29.6 & 21.6 & 19.3 \\
\hline Min Temp $\left({ }^{\circ} \mathrm{C}\right)$ & -3.1 & 1.2 & 4.8 & 6.4 & 12.4 & 16.1 & 21.1 & 17.8 & 12.7 & 7.3 & 3.2 & 0.3 \\
\hline Mean Temp $\left({ }^{\circ} \mathrm{C}\right)$ & 6.9 & 11.4 & 13.6 & 16.0 & 20.3 & 25.5 & 29.5 & 27.6 & 23.0 & 18.0 & 13.5 & 9.7 \\
\hline Rainfall (mm) & 209.6 & 37.4 & 17.4 & 40.4 & 24.2 & 14.4 & 8.2 & 0.6 & 12.6 & 50.2 & 202.6 & 261.4 \\
\hline \multirow{2}{*}{$\begin{array}{l}\text { Weather } \\
\text { Parameter }\end{array}$} & \multicolumn{12}{|c|}{2018 (Second Experimental Year) } \\
\hline & January & February & March & April & May & June & July & August & September & October & November & December \\
\hline $\operatorname{Max} \operatorname{Temp}\left({ }^{\circ} \mathrm{C}\right)$ & 17.3 & 18.4 & 24.6 & 30.9 & 31.9 & 34.7 & 36.2 & 35.7 & 35.2 & 28.7 & 28.4 & 18.8 \\
\hline Min Temp $\left({ }^{\circ} \mathrm{C}\right)$ & 1.3 & 3.7 & 4.8 & 8.2 & 13.7 & 16.1 & 18.7 & 18.7 & 15.3 & 8.0 & 15.0 & 0.4 \\
\hline Mean Temp $\left({ }^{\circ} \mathrm{C}\right)$ & 9.4 & 10.4 & 13.3 & 18.9 & 21.8 & 24.1 & 26.7 & 27.1 & 23.9 & 19.8 & 4.7 & 9.3 \\
\hline Rainfall (mm) & 96.2 & 235.4 & 142.0 & 9.6 & 53.2 & 103.6 & 50.8 & 8.0 & 10.8 & 39.0 & 139.0 & 71.4 \\
\hline
\end{tabular}

${ }^{1}$ Max temp, min temp, and mean temp denote the maximum temperature, minimum temperature, and mean temperature, respectively, for each month.

\subsection{Experimental Setup}

Before describing the field activities from the establishment year (2016) to the final experimental year (2018), it has to be noted that the experiment was conducted according to a split plot design which was employed in a randomized complete block design (RCBD) with four replications. Two alfalfa cultivars ("Ypati 84" and "Hyliki") were assigned to main plots and three different irrigation timings were assigned to subplots as the experimental treatments. "Ypati 84" and "Hyliki" (seeds derived from Euroagro S.A., Kilkis, Greece) were chosen since they are the most preferred cultivars from Greek farmers due to their high productivity, vigorous growth, and very good adaptability to the soil and climatic conditions prevailing in the country. Regarding the establishment of both the alfalfa cultivars, the field was disced on 9 May 2016. The field was fertilized with $45 \mathrm{~kg} \mathrm{~N} \cdot \mathrm{ha}^{-1}$, $150 \mathrm{~kg} \mathrm{P}_{2} \mathrm{O}_{5} \cdot \mathrm{ha}^{-1}$, and $45 \mathrm{~kg} \mathrm{~K}_{2} \mathrm{O} \cdot \mathrm{ha}^{-1}$ (Trifolin, Hellenic Fertilizers and Chemicals Elfe S.A., Athens, Paleo Faliro, Greece). The discing operation was followed by spring-tooth harrowing to further break soil clods, smooth the field, and incorporate the broadcast fertilizer at $30 \mathrm{~cm}$ depth. A cultipacker (Krosker, Agricultural Machinery-S. Milonas 1983 O.E., Thessaloniki, Adendro, Greece) was run on the field as a final operation. The machinery consisted of a $3.6 \mathrm{~m}$ wide hydraulic cylinder equipped with 30 tooth wheels, as well as four rim wheels, to be towed on the field. This action was performed to crush any remaining soil clods and finish seedbed firming. This operation is a common practice adopted by Greek farmers for seedbed preparation for several arable crops. Alfalfa seeding was performed with a pneumatic seed drill (Pinta, M. Gaspardo S.p.A., Veneto, Campodarsego, Italy) on 10 May 2016 at the seeding rate of $35 \mathrm{~kg} \cdot \mathrm{ha}^{-1}$ with $3 \mathrm{~cm}$ depth in the rows. Row spacing was $20 \mathrm{~cm}$. Initial irrigations were carried out with sprinklers (Grouner 1938, Demiroglou, Sot., \& Sons O.E., Grouner-Dischargers of Artificial Rain, Thessaloniki, Greece) to stimulate alfalfa emergence.

The subplot size was $8.1 \mathrm{~m}$ wide by $6 \mathrm{~m}$ long. The explanations rely upon the fact that furrow irrigation (e.g., border flooding) was the method of irrigation adopted. This method was preferred over sprinkler irrigation since the target of this study was to evaluate different irrigation timings, and this would not be possible if all the subplots were simultaneously irrigated from a sprinkler. Although the subsurface drip irrigation system and similar systems are more efficient since alfalfa is irrigated with precision and focus on the root zone [17], they were not adopted in this study since their use does not represent the common practices of the alfalfa growers in the country. In fact, flood irrigation systems are dominant in the alfalfa fields of Greece since they are inexpensive not only in system 
but also in energy costs. In any case, to apply the method of furrow irrigation, the subplots were ploughed to form six ridges $1 \mathrm{~m}$ wide in each plot with furrows located in the right and the left side of each ridge. The furrows were $30 \mathrm{~cm}$ wide and $30 \mathrm{~cm}$ deep as suggested by the experimental procedures of Xiao et al. [14]. As a result, each subplot was $8.1 \mathrm{~m}$ wide by $6 \mathrm{~m}$ long with a total area of $48.6 \mathrm{~m}^{2}$. A distance of approximately $50 \mathrm{~cm}$ was kept between the neighboring subplots. In 2016, the forage was harvested three times until September, irrigated, and left to fall in dormancy. No weed control operations were carried out and no data were collected from the harvests of the establishment year since this study was targeted to the second and third years, which are the most productive years for the crop.

As for the experimental years, initial irrigations were performed in mid-April for both 2017 and 2018. In both years, alfalfa cultivars were harvested each time they reached the $10 \%$ bloom stage, yielding five harvests for each year. In particular, the first harvest of 2017 occurred on 6 May and the following harvests were carried out on 7 June, 9 July, 12 August, and 15 September. The crop was irrigated to fall in dormancy, and the five harvests were repeated in the following experimental year. The harvests of 2018 were conducted on 5 May, 7 June, 8 July, 10 August, and 13 September. The experimental treatments consisted of three different irrigation timings around the harvest events. From the well, the water was delivered to a pressure hose (PE 75, Technoplastik S.A., Thessaloniki, Sindos, Greece) through a diesel-powered water pump (MA80, Chrysafis K. \& I. O.E., Thessaloniki, Diavata, Greece). The hose was placed each time in the top of each furrow for the flooding. The experimental treatments (e.g., irrigation timings) were, in most cases, applied at the rate of $100 \mathrm{~mm}$ per irrigation. The first irrigation timing (IT-1) provided the irrigation of alfalfa 1 week before clipping. For the second irrigation timing (IT-2), the stand was irrigated 1 week after clipping, while, for the third irrigation timing (IT-3), the irrigation of the crop was delayed by 2 weeks after clipping. However, weed and yield data were obtained in the subsequent clipping. For example, IT- 1 treatment means that the crop was irrigated 1 week before the first harvest, and the relative data of weed pressure, forage yield, and quality were obtained in the second harvest event. The same has to be noted for the other two irrigation timings (IT-2, IT-3). Similarly, regarding the data obtained from the fourth harvest, they were attributed to the irrigation timing adopted around the third harvest (Table 2).

Table 2. Definition of the experimental treatments. The different irrigation timings, i.e., treatments applied around the first and the third harvest were evaluated in the second and the fourth harvest, respectively.

\begin{tabular}{ccc}
\hline Irrigation Timing (IT) & Definition & Data Collection \\
\hline IT-1 & 1 week before the first harvest & Second harvest \\
IT-2 & 1 week after the first harvest & Second harvest \\
IT-3 & 2 weeks after the first harvest & Second harvest \\
\hline IT-1 & 1 week before the third harvest & Fourth harvest \\
IT-2 & 1 week after the third harvest & Fourth harvest \\
IT-3 & 2 weeks after the third harvest & Fourth harvest \\
\hline
\end{tabular}

It was hypothesized that irrigating the stand before or after a clipping event would affect the emergence of weeds in the stand, as well as the regrowth ability of alfalfa. The measurements were carried out in the subsequent clipping, to study the effects of irrigation timing on the ability of the crop to compete with the weeds and maintain its productivity. The data of forage yield and quality were collected from separate harvests instead of presenting total values for the 2 years since the composition of the weed flora varied from the initial to the following harvests, as presented in Section 3. 


\subsection{Data Collection}

After the first harvest of 2017, eight metallic $0.25 \mathrm{~m}^{2}$ quadrats were in each subplot, away from the plot margins, in appropriate areas where the weed flora was uniform before harvest. The next action was to mark the plants with rings as suggested by Mattera et al. [13] so as to be able to count the actual number of alfalfa plants and define the density of the stand. These areas were permanently marked with vertical stakes to enable us to perform the same activity in 2018. Before the second harvest, both in 2017 and in 2018, weed data were collected. After identifying the major weed species present in the quadrats, weeds counts were performed on species level to measure the number of weeds per unit area. To measure also the overall density of weeds, the small densities of other species (e.g., Setaria faberi Herrm., Xanthium strumarium L., Polygonum aviculare L.) were also integrated along with the densities of the dominant weeds. Afterward, the aboveground weed biomass was harvested by clipping the vegetation with scissors at approximately $5 \mathrm{~cm}$ height and stored carefully in large number-marked plastic bags. The harvested weed vegetation was oven-dried for $48 \mathrm{~h}$ at $65{ }^{\circ} \mathrm{C}$, and the weed aboveground biomass per unit area was measured on a species level. Total weed biomass per unit area was also measured. The same course of actions was performed right before the fourth harvest of the crop, in both the experimental years. Weed density and weed biomass data were expressed as number of plants and grams per square meter, respectively.

Alfalfa was harvested by clipping the plants, in each quadrat, with scissors at $6 \mathrm{~cm}$ height. The collected forage of alfalfa was also oven-dried for $48 \mathrm{~h}$ at $65^{\circ} \mathrm{C}$ to determine forage yield per unit area. The remaining forage was mown in each subplot with a small plot harvester (Haldrup C-60, Løgstør, Denmark). To get the values for the components of forage yield, e.g., stand density, number of stems per plant, and mass per stem [7], the following actions were carried out: since stand density was measured in situ, the collected forage was used to define the values of the other two components of yield. The number of stems, derived from the harvested areas, was counted to calculate the ratio of the number of stems to the number of plants per unit area and to estimate the values of the number of stems produced per plant. The dry mass accumulated per stem was the component of yield calculated as the ratio of forage yield to the number of stems. Regarding the two forage quality traits studied, the leaves were separated from the stems and weighted separately to calculate the leaf per stem ratio. The conventional chemical analysis of Kjeldahl $(N \% \times 6.25)$ was conducted to determine crude protein. For performing this analysis, the model Vapodest $50 \mathrm{~s}$ (Gerhardt Analytical Systems-C. Gerhardt GmbH \& Co. KG, C., Königswinter, Germany) model was used (fully automated with manual sample changes required).

\subsection{Statistical Analysis}

Normal distribution of all the data was checked with Shapiro and Wilk's test [40], while their homoscedasticity was tested by performing Levene's test [41]. For each separate harvest, the data were subjected to an analysis of variance (ANOVA) using STATGRAPHICS Centurion XVI. Analyses were performed at the $\alpha=0.05$ significance level. The factors of cultivar (C), irrigation timing (IT), and year (Y), as well as the interactions between these factors, were considered as fixed effects, while the factor of replication was considered as a random effect. Multiple comparisons (post hoc tests) were performed to separate means among treatments using Fischer's least significant difference (LSD) test at the $\alpha=0.05$ significance level. For both the second and the fourth harvests, regression analyses were also performed, at the $\alpha=0.05$ significance level, using the same statistical software, according to the following linear model:

$$
Y=A+B \times X,
$$

where $Y$ represents the values of alfalfa forage yield, and $X$ represents the values of the total number of weeds per unit area. 


\section{Results}

\subsection{Weed Presence}

As observed in the second harvest of alfalfa, the major weed species were black nightshade (Solanum nigrum L.) and common lambsquarters (Chenopodium album L.). Significant were the effects of irrigation timing (IT) on the densities of these weeds $(p \leq 0.001)$. The same outcome was noticed for the density of redroot pigweed (Amaranthus retroflexus L.), which was the dominant species in the stand at the fourth harvest of the crop (Table 3). Total weed density was also influenced by the adoption of different irrigation timings either in the second or in the fourth harvest $(p \leq 0.001)$. A significant interaction emerged between the cultivars $(\mathrm{C})$ and years $(\mathrm{Y})$ for the cases of common lambsquarters and redroot pigweed $(p \leq 0.05)$. The integrated effects of the different cultivars (C) and irrigation timings (IT) were also significant regarding the density of common lambsquarters $(p \leq 0.05)$.

Table 3. The effects of the experimental factors on the weed density values recorded, in the second and the fourth harvest, across the two experimental years. Solanum nigrum and Chenopodium album L. were the dominant species during the second harvest. Amaranthus retroflexus L. was the dominant species during the fourth harvest. The $p$-values were derived from an analysis of variance.

\begin{tabular}{|c|c|c|c|c|c|}
\hline \multirow[b]{2}{*}{ Factor } & \multicolumn{3}{|c|}{ Second Harvest } & \multicolumn{2}{|c|}{ Fourth Harvest } \\
\hline & Solanum nigrum (L.) & Chenopodium album (L.) & Total Weed Density & $\begin{array}{l}\text { Amaranthus } \\
\text { retroflexus (L.) }\end{array}$ & Total Weed Density \\
\hline Cultivar (C) & ns & ns & ns & ns & ns \\
\hline Irrigation Timing (IT) & $* * *$ & $* * *$ & $* * *$ & $* * *$ & $* * *$ \\
\hline Year $(Y)$ & ns & ns & ns & ns & ns \\
\hline $\mathrm{C} \times \mathrm{IT}$ & ns & $*$ & ns & ns & ns \\
\hline $\mathrm{C} \times \mathrm{Y}$ & ns & $*$ & ns & $*$ & $*$ \\
\hline $\mathrm{IT} \times \mathrm{Y}$ & ns & ns & ns & ns & ns \\
\hline $\mathrm{C} \times \mathrm{IT} \times \mathrm{Y}$ & ns & ns & ns & ns & ns \\
\hline
\end{tabular}

ns, nonsignificant; ${ }^{*}$, and ${ }^{* *}$ denote significance at 0.05 , and 0.001 , respectively.

According to the results of the multiple comparisons, irrigating the stand 1 week before the first harvest of alfalfa (IT-1) resulted in 79\% lower black nightshade density in the second harvest as compared to the case where the irrigation was carried out 1 week after the first harvest (IT-2). Adoption of the IT- 1 treatment also reduced the density of this weed by $54 \%$ as compared to the IT- 3 treatment. Another outcome noticed in the second harvest was that delaying the irrigation 2 weeks after the first clipping (IT-3) led to a $56 \%$ reduction in black nightshade density in comparison to the IT-2 treatment (Table 4). Moreover, the irrigation 1 week after the first harvest (IT-2) increased the density of common lambsquarters in the second harvest by $49 \%$ as compared to the values obtained when the irrigation was delayed by 1 more week (IT-3). Irrigating the stand 1 week before the first harvest (IT-1) reduced the density of this weed by $61 \%$ as compared to the case where the stand was irrigated 1 week after the first harvest (IT-2). Similar observations were made regarding total weed density, which was highest in the subplots of IT-2 treatment; significantly lower values corresponded to the other two irrigation timings (IT-1, IT-3). As observed in the fourth harvest where the stand was mainly infested with redroot pigweed, the irrigation 1 week prior to the third clipping (IT-1) led to a significant reduction $(42 \%)$ in comparison to delaying the irrigation 2 weeks after the third clipping (IT-3). The irrigation 1 week after the third harvest (IT-2) was a harmful treatment for the crop since it increased the presence of this weed by $41 \%$ and $66 \%$ as compared to IT- 3 and IT- 1 treatments, respectively. Concerning total weed density in the fourth harvest, it received its lowest values under IT-1 treatment. In addition, IT- 3 treatment decreased weed density by up to $35 \%$ in comparison to IT-2 treatment. 
Table 4. The weed density (plants $\cdot \mathrm{m}^{-2}$ ) values recorded, in the second and the fourth harvest, across the two experimental years. Solanum nigrum and Chenopodium album L. were the dominant species during the second harvest. Amaranthus retroflexus L. was the dominant species during the fourth harvest.

\begin{tabular}{|c|c|c|c|c|c|}
\hline \multirow[b]{2}{*}{ Factor } & \multicolumn{3}{|c|}{ Second Harvest } & \multicolumn{2}{|c|}{ Fourth Harvest } \\
\hline & $\begin{array}{l}\text { Solanum nigrum } \\
\text { (L.) }\end{array}$ & $\begin{array}{l}\text { Chenopodium } \\
\text { album (L.) }\end{array}$ & $\begin{array}{l}\text { Total Weed } \\
\text { Density }\end{array}$ & $\begin{array}{l}\text { Amaranthus } \\
\text { retroflexus (L.) }\end{array}$ & $\begin{array}{c}\text { Total Weed } \\
\text { Density }\end{array}$ \\
\hline \multicolumn{6}{|l|}{ Cultivar } \\
\hline Ypati 84 & $9.50 \mathrm{a}^{1}$ & $10.67 \mathrm{a}$ & $22.50 \mathrm{a}$ & $18.25 \mathrm{a}$ & $21.50 \mathrm{a}$ \\
\hline Hyliki & $8.00 \mathrm{a}$ & $10.50 \mathrm{a}$ & $21.33 \mathrm{a}$ & $18.50 \mathrm{a}$ & $21.75 \mathrm{a}$ \\
\hline \multicolumn{6}{|c|}{ Irrigation Timing } \\
\hline IT-1 & $3.25 c$ & $6.50 \mathrm{~b}$ & $11.50 \mathrm{~b}$ & $9.75 c$ & $12.87 \mathrm{c}$ \\
\hline IT-2 & $16.00 \mathrm{a}$ & $16.75 \mathrm{a}$ & $36.25 \mathrm{a}$ & $28.50 \mathrm{a}$ & $32.00 \mathrm{a}$ \\
\hline IT-3 & $7.00 \mathrm{~b}$ & $8.50 \mathrm{~b}$ & $18.00 \mathrm{~b}$ & $16.87 \mathrm{~b}$ & $20.00 \mathrm{~b}$ \\
\hline \multicolumn{6}{|l|}{ Year } \\
\hline 2017 & $8.67 \mathrm{a}$ & $9.83 \mathrm{a}$ & $20.67 \mathrm{a}$ & $17.00 \mathrm{a}$ & $20.25 \mathrm{a}$ \\
\hline 2018 & $8.83 \mathrm{a}$ & $11.33 \mathrm{a}$ & $21.17 \mathrm{a}$ & $19.75 \mathrm{a}$ & $23.00 \mathrm{a}$ \\
\hline
\end{tabular}

${ }^{1}$ The different lowercase letters within the same column indicate significant differences between the cultivars, the treatments, and the years after the mean separations carried out by Fisher's least significant difference (LSD) test at $p \leq 0.05$.

The measurements of weed biomass were in accordance with the corresponding of weed density (Table 5). The ANOVA indicated significant differences $(p \leq 0.001)$ between the irrigation timings (IT) regarding the dry weights of black nightshade and common lambsquarters (second harvest), as well as the dry weight per unit area recorded for redroot pigweed (fourth harvest). For both harvests, total weed biomass was significantly affected by the different irrigation timings $(p \leq 0.001)$. Significant $(p \leq 0.05)$ was the interaction between the cultivars $(\mathrm{C})$ and years $(\mathrm{Y})$ for common lambsquarters in the second harvest, as well as for redroot pigweed and total weed biomass in the fourth harvest. In addition, the interaction among the factors of cultivar (C) and irrigation timing (IT) was significant for the biomass values obtained for common lambsquarters at the second harvest $(p \leq 0.05)$.

Table 5. The effects of the experimental factors on the weed biomass values recorded, in the second and the fourth harvest, across the two experimental years. Solanum nigrum and Chenopodium album L. were the dominant species during the second harvest. Amaranthus retroflexus L. was the dominant species during the fourth harvest. The $p$-values were derived from an analysis of variance.

\begin{tabular}{|c|c|c|c|c|c|}
\hline \multirow[b]{2}{*}{ Factor } & \multicolumn{3}{|c|}{ Second Harvest } & \multicolumn{2}{|c|}{ Fourth Harvest } \\
\hline & $\begin{array}{l}\text { Solanum nigrum } \\
\text { (L.) }\end{array}$ & $\begin{array}{l}\text { Chenopodium } \\
\text { album (L.) }\end{array}$ & $\begin{array}{c}\text { Total Weed } \\
\text { Biomass }\end{array}$ & $\begin{array}{l}\text { Amaranthus } \\
\text { retroflexus (L.) }\end{array}$ & $\begin{array}{c}\text { Total Weed } \\
\text { Biomass }\end{array}$ \\
\hline Cultivar (C) & ns & ns & ns & ns & ns \\
\hline Irrigation Timing (IT) & $* * *$ & $* * *$ & $* * *$ & $* * *$ & $* * *$ \\
\hline Year $(\mathrm{Y})$ & ns & ns & ns & ns & ns \\
\hline $\mathrm{C} \times \mathrm{IT}$ & ns & * & ns & ns & ns \\
\hline $\mathrm{C} \times \mathrm{Y}$ & ns & $*$ & ns & $*$ & $*$ \\
\hline $\mathrm{IT} \times \mathrm{Y}$ & ns & ns & ns & ns & ns \\
\hline $\mathrm{C} \times \mathrm{IT} \times \mathrm{Y}$ & ns & ns & ns & ns & ns \\
\hline
\end{tabular}

ns, nonsignificant, ${ }^{*}$, and ${ }^{* * *}$ denote significance at 0.05 , and 0.001 , respectively.

The results of the post hoc tests revealed that the IT- 1 treatment decreased the biomass of black nightshade by $56 \%$ as compared to the IT-3 treatment (Table 6). Significant differences were obtained between IT- 1 and IT- 2 treatments in the second harvest of alfalfa. In particular, irrigating the stand 1 week after the first clipping (IT-2) resulted in 50\% and $82 \%$ more biomass accumulation for common lambsquarters and black nightshade, respectively, as compared to the case where the stand was irrigated 1 week before the first 
clipping (IT-1). In addition, delayed irrigation for 2 weeks after the first harvest (IT-3) resulted in lower $(42-60 \%)$ dry weight per unit area in the second harvest for both these broadleaves in comparison to IT-2 treatment. Total weed biomass was also significantly lower in the subplots of IT-1 treatment than in the subplots where the other two irrigation timings were adopted (IT-2, IT-3). The slight increase in black nightshade biomass in the plots of "Ypati 84" as compared to the corresponding values observed in the plots of "Hyliki" was not significant. The same has to be noted for the slight differences observed among the two years regarding common lambsquarters biomass values.

Table 6. The weed biomass $\left(\mathrm{g} \cdot \mathrm{m}^{-2}\right)$ values recorded, in the second and the fourth harvest, across the two experimental years. Solanum nigrum and Chenopodium album L. were the dominant species during the second harvest. Amaranthus retroflexus L. was the dominant species during the fourth harvest.

\begin{tabular}{|c|c|c|c|c|c|}
\hline \multirow[t]{2}{*}{ Factor } & \multicolumn{3}{|c|}{ Second Harvest } & \multicolumn{2}{|c|}{ Fourth Harvest } \\
\hline & $\begin{array}{l}\text { Solanum nigrum } \\
\text { (L.) }\end{array}$ & $\begin{array}{l}\text { Chenopodium } \\
\text { album (L.) }\end{array}$ & $\begin{array}{l}\text { Total Weed } \\
\text { Biomass }\end{array}$ & $\begin{array}{l}\text { Amaranthus } \\
\text { retroflexus (L.) }\end{array}$ & $\begin{array}{c}\text { Total Weed } \\
\text { Biomass }\end{array}$ \\
\hline \multicolumn{6}{|l|}{ Cultivar } \\
\hline Ypati 84 & $126.874 \mathrm{a}^{1}$ & $123.397 \mathrm{a}$ & $287.216 \mathrm{a}$ & $264.093 \mathrm{a}$ & $294.144 \mathrm{a}$ \\
\hline Hyliki & $102.732 \mathrm{a}$ & $130.564 \mathrm{a}$ & $265.579 \mathrm{a}$ & $255.162 \mathrm{a}$ & $288.560 \mathrm{a}$ \\
\hline \multicolumn{6}{|c|}{ Irrigation Timing } \\
\hline IT-1 & $38.556 c$ & $93.192 \mathrm{~b}$ & $165.107 \mathrm{~b}$ & $149.488 \mathrm{c}$ & $181.523 \mathrm{c}$ \\
\hline IT-2 & $217.919 \mathrm{a}$ & $186.361 \mathrm{a}$ & $436.176 \mathrm{a}$ & $387.711 \mathrm{a}$ & $423.441 \mathrm{a}$ \\
\hline IT-3 & $87.838 \mathrm{~b}$ & $107.389 \mathrm{~b}$ & $227.909 \mathrm{~b}$ & $241.686 \mathrm{~b}$ & $269.391 \mathrm{~b}$ \\
\hline \multicolumn{6}{|l|}{ Year } \\
\hline 2017 & $116.087 \mathrm{a}$ & $119.272 \mathrm{a}$ & $263.774 \mathrm{a}$ & $244.497 \mathrm{a}$ & $278.840 \mathrm{a}$ \\
\hline 2018 & $111.522 \mathrm{a}$ & $138.689 \mathrm{a}$ & $289.021 \mathrm{a}$ & $274.758 \mathrm{a}$ & $303.866 \mathrm{a}$ \\
\hline
\end{tabular}

${ }^{1}$ The different lowercase letters within the same column indicate significant differences between the cultivars, the treatments, and the years after the mean separations carried out by Fisher's least significant difference (LSD) test at $p \leq 0.05$.

Significant differences were detected among all the irrigation timings regarding the biomass of redroot pigweed individuals, as noted in the fourth harvest of alfalfa (Table 6). In particular, the IT-2 treatment aggravated the levels of redroot pigweed infestation since its adoption increased the biomass of this weed by $37 \%$ and $61 \%$ as compared to IT- 3 and IT-1 treatments, respectively. Moreover, the irrigation 1 week before the third harvest (IT-1) resulted in lower (approximately 38\%) redroot pigweed biomass in the fourth harvest than in the case where the irrigation was carried out 2 weeks after the third harvest (IT-3). The biomass of this weed tended to increase in some subplots from the first to the second experimental year; however, the means did not differ significantly. Regarding the total dry weight accumulated from the weeds per unit area, it was by approximately $32 \%$ and $57 \%$ higher in the subplots of the IT-2 treatment as compared to the subplots of the IT- 3 and IT-1 treatments, respectively. Moreover, weeds produced 36\% more biomass under the IT-3 treatment than under the IT-1 treatment.

\subsection{Forage Yield}

The overall effects of the factors of cultivar (C) and irrigation timing (IT) on the values of stand density, as well as the number of stems per plant, were not proven statistically significant. The same was noted regarding the significance of the interactions between the experimental factors (Table 7). However, both these components of yield were significantly affected by the factor of year $(Y)(p \leq 0.05)$. On the contrary, mass per shoot and total forage yield were neither affected by year $(\mathrm{Y})$ and nor by cultivar $(\mathrm{C})$ selection; however, the factor of irrigation timing (IT) exerted a great influence on their values $(p \leq 0.001)$. It has to be noted that this trend was observed both in the second and in the fourth clippings of alfalfa. 
Table 7. The effects of the experimental factors on the stand density, number of shoots per plant, mass per shoot, and forage yield values recorded, in the second and the fourth harvest, across the two experimental years. The $p$-values were derived from an analysis of variance.

\begin{tabular}{|c|c|c|c|c|}
\hline \multirow{2}{*}{ Factor } & \multicolumn{4}{|c|}{ Second Harvest } \\
\hline & Stand Density & Stems Per Plant Ratio & Mass Per Stem & Forage Yield \\
\hline Cultivar $(\mathrm{C})$ & $\mathrm{ns}$ & ns & ns & ns \\
\hline Irrigation Timing (IT) & ns & ns & $* * *$ & $* * *$ \\
\hline Year $(\mathrm{Y})$ & $*$ & $*$ & ns & ns \\
\hline $\mathrm{C} \times \mathrm{IT}$ & ns & ns & ns & $\mathrm{ns}$ \\
\hline $\mathrm{C} \times \mathrm{Y}$ & ns & ns & ns & ns \\
\hline $\mathrm{IT} \times \mathrm{Y}$ & ns & ns & ns & ns \\
\hline $\mathrm{C} \times \mathrm{IT} \times \mathrm{Y}$ & ns & ns & ns & ns \\
\hline \multirow{2}{*}{ Factor } & \multicolumn{4}{|c|}{ Fourth Harvest } \\
\hline & Stand Density & Stems Per Plant Ratio & Mass Per Stem & Forage Yield \\
\hline Cultivar $(\mathrm{C})$ & ns & ns & ns & ns \\
\hline Irrigation Timing (IT) & ns & ns & $* * *$ & $* * *$ \\
\hline Year $(\mathrm{Y})$ & * & * & ns & ns \\
\hline $\mathrm{C} \times \mathrm{IT}$ & ns & ns & ns & ns \\
\hline $\mathrm{C} \times \mathrm{Y}$ & ns & ns & ns & ns \\
\hline $\mathrm{IT} \times \mathrm{Y}$ & ns & ns & ns & ns \\
\hline $\mathrm{C} \times \mathrm{IT} \times \mathrm{Y}$ & ns & ns & ns & ns \\
\hline
\end{tabular}

ns, nonsignificant; ${ }^{*}$, and ${ }^{* * *}$ denote significance at 0.05 , and 0.001 , respectively.

Regarding the density of alfalfa plants in the stand, its value was $13 \%$ lower during 2018 than the corresponding value recorded during 2017 (Table 8). The opposite trend was observed for the stems per plant ratio since the number of stems per plant produced during 2018 was significantly higher than that during 2017, both in the second and in the fourth harvests of alfalfa. Although mass per stem was not affected by years and cultivars, the values of this component varied among the different irrigation timings adopted. In particular, as observed in the second clipping, mass per stem was increased by almost $30 \%$ in the subplots where the irrigation was carried out 1 week before the first clipping (IT-1) as compared to the values obtained in the subplots where the stand was irrigated 1 week after the first clipping (IT-2). Furthermore, delaying the irrigation 2 weeks after the first harvest, (IT-3) enabled the production of $28 \%$ more mass per individual stem in comparison to IT-2 treatment. In the fourth harvest, it was noted that the irrigation 1 week prior to the third harvest (IT-1) increased the values of this component of yield by $17 \%$ and $36 \%$ as compared to IT- 3 and IT- 2 treatments, respectively. The delayed irrigation by 2 weeks after the third clipping (IT-3) resulted in approximately $24 \%$ higher mass per stem values (in the fourth harvest) than the corresponding values obtained in the subplots where the stand was irrigated 1 week after the third clipping (IT-2).

As observed in the second harvest, the forage yield of alfalfa was $28 \%$ and $31 \%$ lower when the crop was irrigated 1 week after the first harvest (IT-2) in comparison to the cases where the irrigation was performed 2 weeks after (IT-3) and 1 week before (IT-1) the first harvest, respectively (Table 8).

In addition, alfalfa yield performance was affected by weed presence in the second harvest (Figure 1). A linear model was used to correlate total weed density and alfalfa forage yield $(Y=4.90695-0.0516315 X ; n=48 ; p<0.001$; root-mean-square error $($ RMSE $)=0.224)$. The regression was negative given the value of the correlation coefficient $(R=-0.934)$ and also strong given the value of the coefficient of determination $\left(R^{2}=87.013 \%\right)$. A similar trend was observed in the fourth harvest (Figure 2). Weed density and alfalfa were negatively $(R=-0.911)$ correlated $(Y=2.75561-0.0418589 X ; n=48 ; p<0.001 ; \operatorname{RMSE}=0.259)$, and the regression was again important $\left(R^{2}=82.691 \%\right)$. 
Table 8. The stand density (plants $\cdot \mathrm{m}^{-2}$ ), stems per plant ratio (stems $\cdot$ plant ${ }^{-1}$ ), yield per shoot $\left(\mathrm{g} \cdot\right.$ shoot $^{-1}$ ), and forage yield $\left(\mathrm{t} \cdot \mathrm{ha}^{-1}\right)$ values recorded, in the second and the fourth harvest, across the two experimental years.

\begin{tabular}{|c|c|c|c|c|}
\hline \multirow[b]{2}{*}{ Factor } & \multicolumn{4}{|c|}{ Second Harvest } \\
\hline & $\begin{array}{l}\text { Stand Density } \\
\left(\text { Plants } \cdot \mathrm{m}^{-2}\right)\end{array}$ & $\begin{array}{l}\text { Stems Per Plant Ratio } \\
\left(\text { Stems } \cdot \text { Plant }^{-1}\right)\end{array}$ & $\begin{array}{l}\text { Mass Per Stem } \\
\left(\mathrm{g} \cdot \text { stem }^{-1}\right)\end{array}$ & Forage Yield $\left(t \cdot h a^{-1}\right)$ \\
\hline \multicolumn{5}{|l|}{ Cultivar } \\
\hline Ypati 84 & $158.83 \mathrm{a}$ & $4.13 \mathrm{a}$ & $0.598 \mathrm{a}$ & $3.774 \mathrm{a}$ \\
\hline Hyliki & $160.67 \mathrm{a}$ & $4.11 \mathrm{a}$ & $0.592 \mathrm{a}$ & $3.785 \mathrm{a}$ \\
\hline \multicolumn{5}{|c|}{ Irrigation Timing } \\
\hline IT-1 & $154.44 \mathrm{a}$ & $4.13 \mathrm{a}$ & $0.663 \mathrm{a}$ & $4.256 \mathrm{a}$ \\
\hline IT-2 & $153.50 \mathrm{a}$ & $4.12 \mathrm{a}$ & $0.469 \mathrm{~b}$ & $2.946 \mathrm{~b}$ \\
\hline IT-3 & $154.12 \mathrm{a}$ & $4.12 \mathrm{a}$ & $0.654 \mathrm{a}$ & $4.136 \mathrm{a}$ \\
\hline \multicolumn{5}{|l|}{ Year } \\
\hline 2017 & $170.83 \mathrm{a}$ & $4.04 \mathrm{~b}$ & $0.566 \mathrm{a}$ & $3.783 \mathrm{a}$ \\
\hline 2018 & $148.67 \mathrm{~b}$ & $4.20 \mathrm{a}$ & $0.624 \mathrm{a}$ & $3.775 \mathrm{a}$ \\
\hline \multirow[b]{2}{*}{ Factor } & \multicolumn{4}{|c|}{ Fourth Harvest } \\
\hline & 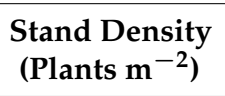 & $\begin{array}{l}\text { Stems Per Plant Ratio } \\
\quad\left(\text { Stems Plant }{ }^{-1}\right)\end{array}$ & $\begin{array}{l}\text { Mass Per Stem } \\
\quad\left(\text { Gstem }^{-1}\right)\end{array}$ & Forage Yield (t ha- $\left.{ }^{-1}\right)$ \\
\hline \multicolumn{5}{|l|}{ Cultivar } \\
\hline Ypati 84 & $158.83 \mathrm{a}$ & $3.95 \mathrm{a}$ & $0.305 \mathrm{a}$ & $1.842 \mathrm{a}$ \\
\hline Hyliki & $160.67 \mathrm{a}$ & $3.94 \mathrm{a}$ & $0.301 \mathrm{a}$ & $1.846 \mathrm{a}$ \\
\hline \multicolumn{5}{|c|}{ Irrigation Timing } \\
\hline IT-1 & $154.44 \mathrm{a}$ & $3.96 \mathrm{a}$ & $0.369 \mathrm{a}$ & $2.260 \mathrm{a}$ \\
\hline IT-2 & $153.50 \mathrm{a}$ & $3.94 \mathrm{a}$ & $0.234 \mathrm{c}$ & $1.396 \mathrm{c}$ \\
\hline IT-3 & $154.12 \mathrm{a}$ & $3.95 \mathrm{a}$ & $0.308 \mathrm{~b}$ & $1.876 \mathrm{~b}$ \\
\hline \multicolumn{5}{|l|}{ Year } \\
\hline 2017 & $170.83 \mathrm{a}$ & $3.87 \mathrm{~b}$ & $0.295 \mathrm{a}$ & $1.887 \mathrm{a}$ \\
\hline 2018 & $148.67 \mathrm{~b}$ & $4.02 \mathrm{a}$ & $0.311 \mathrm{a}$ & $1.801 \mathrm{a}$ \\
\hline
\end{tabular}

The different lowercase letters within the same column indicate significant differences between the cultivars, the treatments, and the years after the mean separations carried out by Fisher's least significant difference (LSD) test at $p \leq 0.05$.

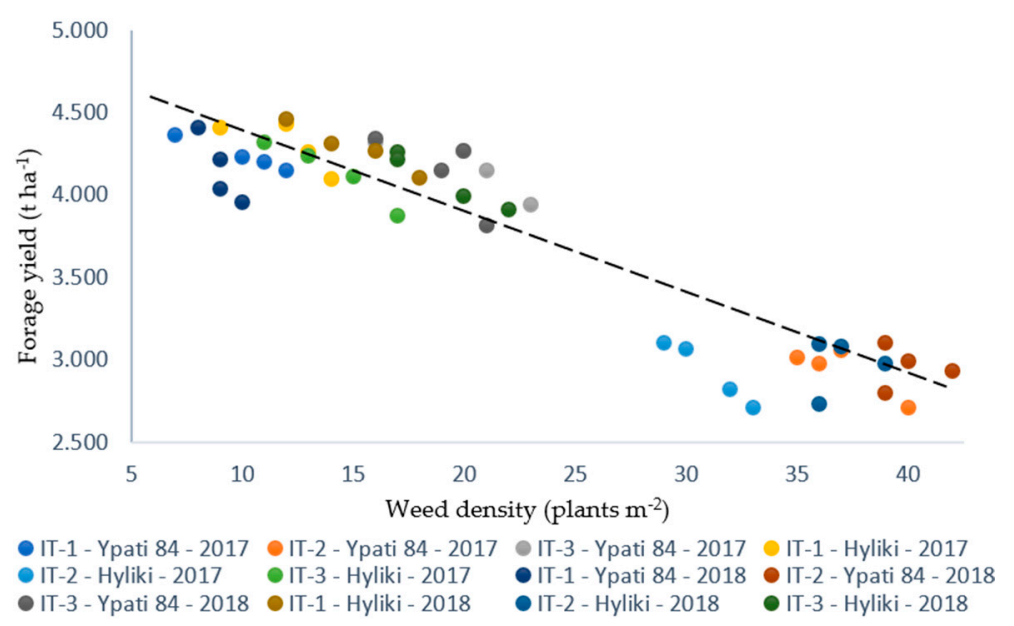

Figure 1. Linear regression between total weed density and alfalfa forage yield in the second harvest. 


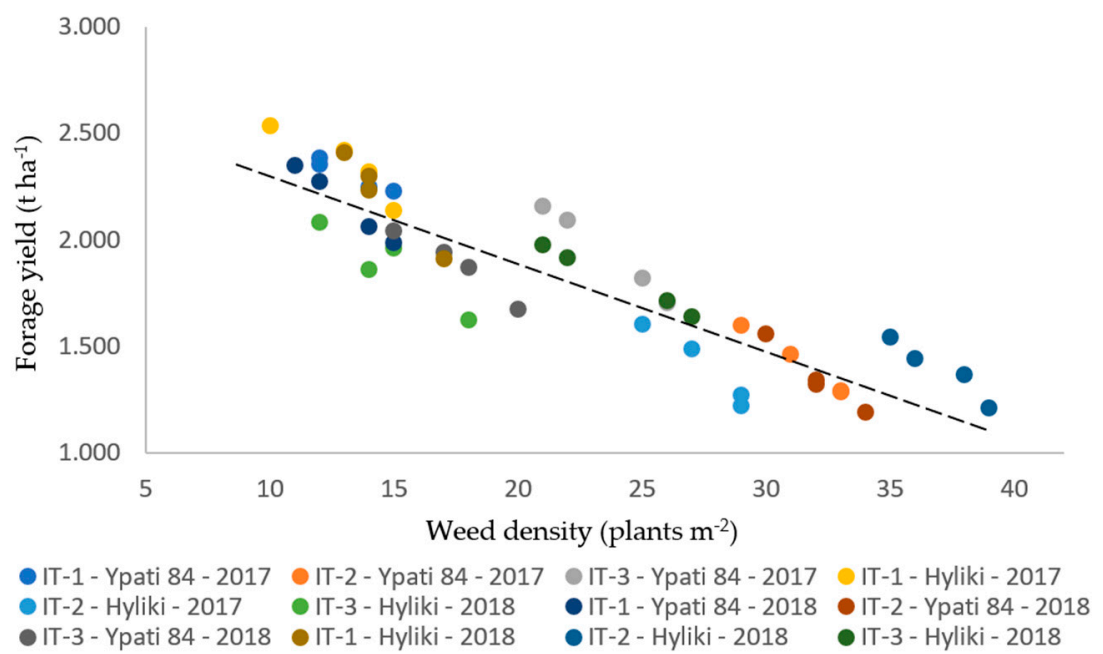

Figure 2. Linear regression between total weed density and alfalfa forage yield in the fourth harvest.

Concerning the forage yield values obtained in the fourth harvest, they were highest under the IT- 1 treatment. In particular, it was revealed that alfalfa was $17 \%$ more productive in the plots irrigated 1 week before the third harvest (IT-1) than in the plots irrigated 2 weeks after the third harvest (IT-3). In the same harvest time, the adoption of IT-1 treatment led to $38 \%$ higher forage yield values than the IT- 2 treatment. Moreover, IT- 3 treatment increased the forage yield of the crop by approximately $25 \%$ as compared to the irrigation performed 1 week after the third clipping (IT-2).

\subsection{Forage Quality}

According to the results of the analysis of variance, the overall effects of irrigation timing (IT) on the values of leaf per stem ratio and crude protein were significant $(p \leq 0.001)$ not only in the second, but also in the fourth harvest of alfalfa (Table 9). For both the harvests, the effects of cultivar $(\mathrm{C})$ and selection year $(\mathrm{Y})$ were not significant on the values of leaf per stem ratio or on the corresponding crude protein. In addition, the interactions between the experimental factors did not influence the values of both the forage quality traits evaluated at the second and the fourth harvest of the crop.

Table 9. The effects of the experimental factors on the leaves per stem ratio (leaves·stem ${ }^{-1}$ ) and crude protein (\%) values recorded, in the second and the fourth harvest, across the two experimental years. The $p$-values were derived from an analysis of variance.

\begin{tabular}{|c|c|c|c|c|}
\hline \multirow{2}{*}{ Factor } & \multicolumn{2}{|c|}{ Second Harvest } & \multicolumn{2}{|c|}{ Fourth Harvest } \\
\hline & $\begin{array}{l}\text { Leaf Per Stem Ratio } \\
\text { (Leaves.Stem }^{-1} \text { ) }\end{array}$ & Crude Protein (\%) & $\begin{array}{c}\text { Leaves Per Stem Ratio } \\
\quad\left(\text { Leaves.Stem }{ }^{-1}\right)\end{array}$ & Crude Protein (\%) \\
\hline Cultivar $(\mathrm{C})$ & ns & ns & ns & ns \\
\hline Irrigation Timing (IT) & $* * *$ & $* * *$ & $* * *$ & $* * *$ \\
\hline Year $(\mathrm{Y})$ & ns & ns & ns & ns \\
\hline $\mathrm{C} \times \mathrm{IT}$ & ns & ns & ns & ns \\
\hline $\mathrm{C} \times \mathrm{Y}$ & ns & ns & ns & ns \\
\hline $\mathrm{IT} \times \mathrm{Y}$ & ns & ns & ns & ns \\
\hline $\mathrm{C} \times \mathrm{IT} \times \mathrm{Y}$ & ns & ns & ns & ns \\
\hline
\end{tabular}

ns, nonsignificant; ${ }^{* * *}$ denote significance at 0.001 , respectively.

The outcome of the post hoc tests revealed that, in the second harvest, the leaf per stem ratio was 19\% increased when the IT- 1 treatment was preferred over the IT- 2 treatment (Table 10). Delaying the irrigation of the stand 2 weeks after the first clipping (IT-3) enhanced the values of the ratio by $17 \%$ as compared to the case where the stand was 
irrigated 1 week after the first clipping (IT-2). In the fourth harvest, the leaf per stem ratio was $11 \%$ and $21 \%$ higher in the subplots irrigated before the third harvest as compared to the values obtained from the subplots of IT- 3 and IT-2 treatments, respectively. The irrigation carried out 2 weeks after the third clipping (IT-3) was also more beneficial for the leaf per stem ratio than the irrigation performed 1 week after the third clipping (IT-2).

Table 10. The leaves per stem ratio (leaves $\cdot$ stem $^{-1}$ ) and crude protein (\%) values recorded, in the second and the fourth harvest, across the two experimental years.

\begin{tabular}{|c|c|c|c|c|}
\hline \multirow[t]{2}{*}{ Factor } & \multicolumn{2}{|c|}{ Second Harvest } & \multicolumn{2}{|c|}{ Fourth Harvest } \\
\hline & $\begin{array}{l}\text { Leaves Per Stem Ratio } \\
\quad\left(\text { Leaves.Stem }{ }^{-1} \text { ) }\right.\end{array}$ & Crude Protein (\%) & $\begin{array}{l}\text { Leaves Per Stem Ratio } \\
\quad\left(\text { Leaves. Stem }{ }^{-1} \text { ) }\right.\end{array}$ & $\begin{array}{c}\text { Crude Protein } \\
(\%)\end{array}$ \\
\hline \multicolumn{5}{|l|}{ Cultivar } \\
\hline Ypati 84 & $0.89 \mathrm{a}$ & $20.51 \mathrm{a}$ & $0.70 \mathrm{a}$ & $19.76 \mathrm{a}$ \\
\hline Hyliki & $0.92 \mathrm{a}$ & $20.66 \mathrm{a}$ & $0.71 \mathrm{a}$ & $19.93 \mathrm{a}$ \\
\hline \multicolumn{5}{|c|}{ Irrigation Timing } \\
\hline IT-1 & $0.97 \mathrm{a}$ & $21.77 \mathrm{a}$ & $0.79 \mathrm{a}$ & $21.19 \mathrm{a}$ \\
\hline IT-2 & $0.79 \mathrm{~b}$ & $18.74 \mathrm{~b}$ & $0.62 c$ & $18.05 \mathrm{c}$ \\
\hline IT-3 & $0.95 \mathrm{a}$ & $21.25 \mathrm{a}$ & $0.70 \mathrm{~b}$ & $20.28 b$ \\
\hline \multicolumn{5}{|l|}{ Year } \\
\hline 2017 & $0.91 \mathrm{a}$ & $20.73 \mathrm{a}$ & $0.73 \mathrm{a}$ & $19.99 \mathrm{a}$ \\
\hline 2018 & $0.88 \mathrm{a}$ & $20.45 a$ & $0.68 \mathrm{a}$ & $19.70 \mathrm{a}$ \\
\hline
\end{tabular}

The different lowercase letters within the same column indicate the significant differences between the cultivars, the treatments, and the years after the mean separations carried out by Fisher's least significant difference (LSD) test at $p \leq 0.05$.

Regarding the crude protein values obtained in the second harvest, they were $12-14 \%$ lower in the subplots of irrigated 1 week after the first harvest (IT-2) than the corresponding values recorded for the subplots where the other two irrigation timings (i.e., IT-1, IT-3) were adopted (Table 10). In the fourth harvest, the irrigation performed 1 week before the third harvest (IT-1) resulted in 5\% and 14\% higher crude protein values than the adoption of IT- 3 and IT- 2 treatments, respectively. In addition, irrigating the stand 2 weeks after the third harvest (IT-3) enhanced the crude protein values by $11 \%$ when this practice was preferred over performing the irrigation 1 week after the third harvest (IT-2).

\section{Discussion}

Forage yield did not vary across the 2 years, but this was attributed to the fact that stand density and the number of stems per plant changed dynamically over the course of time. Although there was not an extreme plant mortality from 2017 to 2018, the year's effect on stand density was significant. This might be attributed to the increased amounts of water deposited in the soil through precipitation during 2018. The high levels of soil moisture might have resulted in soil saturation, a phenomenon which can reduce the available oxygen for the alfalfa rooting system. The creation of saturated soils during the dormancy period is a factor threatening the persistence of alfalfa [42]. The reductions in stand density observed agree with the findings of Ventroni et al. [12], who observed that stand density tends to decrease over the course of years. In any case, the reduction in plant density was counterbalanced by a partial increase in the number of stems per plant. These results are in accordance with Volenec [8]. The mass per stem and forage yield of alfalfa were affected by the different irrigation timings in both years and harvests. Stem mass values tend to increase if there is high availability of nutrients and water to the crop $[9,14]$. Weeds such as common lambsquarters and redroot pigweed are very competitive for resources [43]; low mass per stem values were expected in the highly infested subplots.

Moreover, weed density and alfalfa forage yield were negatively and strongly correlated for both harvests, indicating the impact of weed competition on crop productivity. The lowest weed densities values and the highest yield values were obtained when the 
stand was irrigated before harvest. It is well established that the lack of adequate weed control in established alfalfa can lead to important forage yield losses [2,44]. A reduction of $20 \%$ in forage yield was attributed to the presence of weeds in the control plots of a field trial conducted in established alfalfa fields [36]. Regarding the major weeds occurring in our study, interference from common lambsquarters and redroot pigweed can affect the availability of water to summer crops [43]; a lower water availability can result in $20 \%$ forage yield losses in alfalfa [23]. Earlier studies, conducted under the soil and climatic conditions of Greece, showed that the presence of Solanum spp. could cause 8-26\% forage yield losses [3]. With regard to the quality traits evaluated, it has to be noted that both crude protein and leaf per stem ratio were favored by the availability of water and nutrients in the soil [14,45]. Weeds compete strongly for such resources [26], and their presence might downgrade the quality traits of the collected forage. Similar observations have been made in the past $[33,34]$.

Weed presence was determined from the different irrigation timings. Our results validate that, if irrigation occurs prior to harvest, alfalfa exploits the irrigation water, exhibiting a quick canopy regrowth. As a result, weeds are suppressed due to shading [46]. On the contrary, irrigation a short time after harvest creates the conditions for weeds to outcompete alfalfa and reduce its yield potential. The sufficient soil moisture levels enable weed seeds to germinate [47]; afterward, the emerged weeds exploit the soil moisture and grow rapidly given the absence of a recovered alfalfa canopy $[39,46]$. Similar were the observations of Norris and Ayres [38], who recommended avoiding irrigations soon after harvest to prevent $S$. glauca invasions in the stand. In any case, irrigation management and other cultural practices can be used for weed management in established alfalfa. For instance, Norris and Ayres [38] also suggested that long intervals between harvests can reduce weed infestation in established alfalfa. Grewal [48] used P, K, S, and Zn in fertilizers and managed to suppress weeds by up to $70 \%$ in a 2 year stand of "Aurora" cultivar. Forage yield, crude protein, and leaf per stem ratio were, subsequently, increased [48]. In addition, Celebi et al. [32] used narrow row spacing to displace the weeds from the stand and achieved $40 \%$ higher forage yields. In several cases, including the present study, cultural and integrated weed management strategies have been mentioned to improve the yield potential of alfalfa and the quality traits of the collected forage $[32,38,48]$.

The shift in the weed flora observed between the two harvests agrees with Wilson [35]. In the study mentioned, kochia (Kochia scoparia (L.) Schrad.) and common dandelion (Taraxacum officinale F. H. Wigg.) were the dominant species in June, whereas Setaria pumila (Poir.) Roem. \& Schult. prevailed in July. Similar were the observations of Moyer and Acharya [37], who noted that common dandelion was replaced by downy brome (Bromus tectorum L.). In the current study, the emergence of common lambsquarters was favored by the temperatures of spring and early summer. This species is known for emerging early in the season when lower temperatures prevail in an agricultural area [49,50]. Regarding black nightshade, it seems that the seeds that did not germinate before midsummer might have entered the stage of secondary dormancy given the high temperatures of July [51]. On the contrary, redroot pigweed required the higher temperatures of summer to emerge [52]. An additional explanation for the shift lies in the mowing operations required for harvesting alfalfa. Harvest operations can control summer annuals in the stands of perennial crops $[53,54]$. It seems that several weeds (dominant in the initial harvests) were removed from the stand with the harvests of May and June, and the seeds of the later emergent species, e.g., redroot pigweed, germinated in increased quantities from July, resulting in the dominance of this species during August.

In the past, several studies evaluated the production of alfalfa under different irrigation regimes [18,21,22,24]. Flooding resulted in increased weed pressure as compared to the contemporary method of subsurface drip irrigation [17]. However, this trial was carried out by flooding alfalfa because this practice is widespread in Greece since it is affordable for most farmers. Although irrigation prior to harvest can contribute to developing more effective weed management strategies in established alfalfa, some disadvantages might occur under real field conditions. According to this practice, the alfalfa bales might be left 
for a longer time in the field, increasing the danger of the forage getting wet from possible rain events during the summer. This could negatively affect the quality of the collected forage. In addition, soil compaction can be a problem in heavy soils if the stand is irrigated a short time before harvest [39]. Since a firm soil surface is appropriate for the operation of harvest machines and the drying of the forage in the field, trial-and-error approaches are needed to define the optimum dates for clipping according to the soil and climatic conditions of an agricultural area. In any case, the feedback provided from this study regarding irrigation timing could also be useful in cases where alfalfa is irrigated with the widespread sprinkler system; however, in these cases, attention is needed regarding the management of fungal infections [19].

\section{Conclusions}

Irrigation timing is an agronomic practice that can alleviate established alfalfa from weed pressure. In particular, irrigating the stand prior to harvest can result in lower levels of weed infestation and improve the yield performance of the crop. This practice is also beneficial for the quality traits of the collected forage. Another option is to delay the irrigation until the canopy has partially recovered from a clipping operation. On the contrary, irrigations a short time after harvest stimulate the emergence of weeds, whose presence can lead to reduced alfalfa productivity and downgrade the quality of the forage. Further research is required to validate the use of irrigation timing and more cultural practices in terms of weed management in more perennial forages and under different soil and climatic conditions.

Author Contributions: Conceptualization, P.K.; methodology, P.K., I.G. and I.T.; validation, P.K., I.G. and I.T.; investigation, P.K., I.G. and I.T.; writing original draft preparation, P.K. and I.G.; writing, review and editing, P.K., I.G. and I.T.; supervision, P.K. and I.T.; project administration P.K. All authors have read and agreed to the published version of the manuscript.

Funding: This research received no external funding.

Institutional Review Board Statement: Not applicable.

Informed Consent Statement: Not applicable.

Data Availability Statement: The data presented in this study are available on request from the corresponding author.

Conflicts of Interest: The authors declare no conflict of interest.

\section{References}

1. $\quad$ Edwards, L.E.; Plush, K.J.; Ralph, C.R.; Morrison, R.S.; Acharya, R.Y.; Doyle, R.E. Enrichment with lucerne hay improves sow maternal behaviour and improves piglet survival. Animals 2019, 9, 558. [CrossRef] [PubMed]

2. Travlos, I.S. Forage yield and yield components of spring-seeded alfalfa as affected by seeding rate, cultivar and competitive weed species. In Proceedings of the ASA, CSSA \& SSSA International Annual Meetings, San Antonio, TX, USA, 16-19 October 2011.

3. Travlos, I.S.; Gatos, A.; Kanatas, P.J. Interference between silverleaf nightshade (Solanum elaeagnifolium Cav.) and alfalfa (Medicago sativa L.) cultivars. Hell. Plant Prot. J. 2013, 6, 41-48.

4. Pietsch, G.; Friedel, J.K.; Freyer, B. Lucerne management in an organic farming system under dry site conditions. Field Crops Res. 2007, 102, 104-118. [CrossRef]

5. Li, Y.; Huang, M. Pasture yield and soil water depletion of continuous growing alfalfa in the Loess Plateau of China. Agric. Ecosyst. Environ. 2008, 124, 24-32. [CrossRef]

6. Avci, M.A.; Ozkose, A.; Tamkoc, A. Determination of yield and quality characteristics of alfalfa (Medicago sativa L.) varieties grown in different locations. J. Anim. Vet. Adv. 2013, 12, 487-490.

7. Volenec, J.J.; Cherney, J.H.; Johnson, K.D. Yield Components, plant morphology, and forage quality of alfalfa as influenced by plant population. Crop Sci. 1987, 27, 321-326. [CrossRef]

8. Volenec, J.J. Physiological control of alfalfa growth and yield. In Crop Yield; Smith, D.L., Hamel, C., Eds.; Springer: Berlin/Heidelberg, Germany, 1999; pp. 425-442.

9. Berg, W.K.; Cunningham, S.M.; Brouder, S.M.; Joern, B.C.; Johnson, K.D.; Santini, J.B.; Volenec, J.J. The long-term impact of phosphorus and potassium fertilization on alfalfa yield and yield components. Crop Sci. 2007, 47, 2198-2209. [CrossRef] 
10. Teixeira, E.I.; Moot, D.J.; Brown, H.E.; Fletcher, A.L. The dynamics of lucerne (Medicago sativa L.) yield components in response to defoliation frequency. Eur. J. Agron. 2007, 26, 394-400. [CrossRef]

11. Lloveras, J.; Chocarro, C.; Freixes, O.; Arqué, E.; Moreno, A.; Santiveri, F. Yield, yield components, and forage nutritive value of alfalfa as affected by seeding rate under irrigated conditions. Agron. J. 2008, 100, 191-197. [CrossRef]

12. Ventroni, L.M.; Volenec, J.J.; Cangiano, C.A. Fall dormancy and cutting frequency impact on alfalfa yield and yield components Field Crops Res. 2010, 119, 252-259. [CrossRef]

13. Mattera, J.; Romero, L.A.; Cuatrín, A.L.; Cornaglia, P.S.; Grimoldi, A.A. Yield components, light interception and radiation use efficiency of lucerne (Medicago sativa L.) in response to row spacing. Eur. J. Agron. 2013, 45, 87-95. [CrossRef]

14. Xiao, Y.; Zhang, J.; Jia, T.T.; Pang, X.P.; Guo, Z.G. Effects of alternate furrow irrigation on the biomass and quality of alfalfa (Medicago sativa). Agric. Water Manag. 2015, 161, 147-154. [CrossRef]

15. Saeed, I.A.M.; El-Nadi, A.H. Irrigation effects on the growth, yield, and water use efficiency of alfalfa. Irrig. Sci. 1997, 17, 63-68. [CrossRef]

16. Kandelous, M.M.; Kamai, T.; Vrugt, J.A.; Šimůnek, J.; Hanson, B.; Hopmans, J.W. Evaluation of subsurface drip irrigation design and management parameters for alfalfa. Agric. Water Manag. 2012, 109, 81-93. [CrossRef]

17. Ismail, S.M.; Almarshadi, M.H. Maximizing productivity and water use efficiency of alfalfa under precise subsurface drip irrigation in arid regions. Irrig. Drain. 2013, 62, 57-66. [CrossRef]

18. Cavero, J.; Faci, J.M.; Martinez-Cob, A. Relevance of sprinkler irrigation time of the day on alfalfa forage production. Agric. Water Manag. 2016, 178, 304-313. [CrossRef]

19. Djaman, K.; Smeal, D.; Koudahe, K.; Allen, S. Hay yield and water use efficiency of alfalfa under different irrigation and fungicide regimes in a semiarid climate. Water 2020,12, 1721. [CrossRef]

20. Hanson, B.R.; Bali, K.M.; Sanden, B.L. Irrigating alfalfa in arid regions. In Irrigated Alfalfa Management in Mediterranean and Desert Zones; Summers, C.G., Putnam, D.H., Eds.; University of California, Division of Agriculture and Natural Resources: Oakland, CA, USA, 2008; pp. 89-111.

21. Lodge, G.M. Yield and persistence of irrigated lucerne cut at different frequencies, at Tamworth, New South Wales. Aust. J. Exp. Agric. 1986, 26, 165-172. [CrossRef]

22. Li, Z.; Zhang, W.; Sun, Z. Yield and water use efficiency of non- and single-irrigated alfalfa with ridge and furrow planting in northern China. Agron. J. 2015, 107, 1039-1047. [CrossRef]

23. Holman, J.; Min, D.H.; Klocke, N.; Kisekka, I.; Currie, R. Effects of irrigation amount and timing on alfalfa nutritive value. Trans. $A S A B E$ 2016, 59, 849-860.

24. Li, Y.; Su, D. Alfalfa water use and yield under different sprinkler irrigation regimes in north arid regions of China. Sustainability $2017,9,1380$.

25. Ominski, P.D.; Entz, M.H.; Kendel, N. Weed suppression by Medicago sativa in subsequent cereal crops: A comparative survey. Weed Sci. 1999, 47, 282-290. [CrossRef]

26. Chauhan, B.S. Grand challenges in weed management. Front. Agron. 2020, 1, 3. [CrossRef]

27. Zimdahl, R.L. Fundamentals of Weed Science, 5th ed.; Academic Press: Cambridge, MA, USA, 2018.

28. Fischer, A.J.; Dawson, J.H.; Appleby, A.P. Interference of annual weeds in seedling alfalfa (Medicago sativa). Weed Sci. 1988, 36, 583-588. [CrossRef]

29. Harvey, R.G. Bentazon for annual weed control in newly seeded alfalfa (Medicago sativa L.). Weed Technol. 1991, 5, 154-158. [CrossRef]

30. Stout, W.L.; Byers, R.A.; Leath, K.T.; Bahler, C.C.; Hoffman, L.D. Effects of weed and invertebrate control on alfalfa establishment in oat stubble. J. Prod. Agric. 1992, 5, 349-352. [CrossRef]

31. Annicchiarico, P.; Pecetti, L. Forage and seed yield response of lucerne cultivars to chemically weeded and non-weeded managements ad implications for germplasm choice in organic farming. Eur. J. Agron. 2010, 33, 74-80. [CrossRef]

32. Celebi, S.Z.; Sahar, A.K.; Yergin, R. Effects of the weed density on grass yield of Alfalfa (Medicago sativa L.) in different row spacing applications. African J. Biotechnol. 2010, 9, 6867-6872.

33. Cosgrove, D.R.; Barrett, M. Effects of weed control in established alfalfa (Medicago sativa) on forage yield and quality. Weed Sci. 1987, 35, 564-567. [CrossRef]

34. Spandl, E.; Kells, J.J.; Hesterman, O.B. Weed invasion in established alfalfa (Medicago sativa) seeded with perennial forage grasses. Weed Technol. 1997, 11, 556-560. [CrossRef]

35. Wilson, R.G. New herbicides for weed control in established alfalfa (Medicago sativa). Weed Technol. 1989, 3, 523-526. [CrossRef]

36. Arregui, M.C.; Sánchez, D.; Scotta, R. Weed control in established alfalfa (Medicago sativa) with postemergence herbicides. Weed Technol. 2001, 15, 424-428. [CrossRef]

37. Moyer, J.R.; Acharya, S.N. Impact of cultivars and herbicides on weed management in alfalfa. Can. J. Plant Sci. 2006, 86, 875-885. [CrossRef]

38. Norris, R.F.; Ayres, D. Cutting interval and irrigation timing in alfalfa: Yellow foxtail invasion and economic analysis. Agron. J. 1991, 83, 552-558. [CrossRef]

39. Alam, M.; Rogers, D.H. Irrigation water management for alfalfa. In Irrigation Management Series; Kansas State University, Ed.; Agricultural Experiment Station and Cooperative Extension Service: Manhattan, KS, USA, 2009; pp. 1-8. Available online: https:/ / bookstore.ksre.ksu.edu/pubs/MF2868.pdf (accessed on 20 February 2021). 
40. Shapiro, S.S.; Wilk, M.B. An analysis of variance test for normality (complete samples). Biometrika 1965, 52, 591-611. [CrossRef]

41. Levene, H. Robust tests for equality of variances. In Contributions to Probability and Statistics; Olkin, I., Ed.; Stanford University Press: Stanford, CA, USA, 1960; pp. 278-292.

42. Lang, B.J.; Vittetoe, R.K. Alfalfa Winter Survival-A Complicated Subject. In Integrated Crop Management News; Iowa State University, Ed.; Extension and Experiment Station Publications Collections: Ames, IA, USA, 2019. Available online: https: / / lib.dr.iastate.edu/cgi/viewcontent.cgi?article=3540\&context=cropnews (accessed on 7 March 2021).

43. Zand, E.; Soufizadeh, S.; Eskandari, A. Water stress and nitrogen limitation effects on corn (Zea mays L.) competition with a C3 and a C4 weed. Commun. Agric. Appl. Biol. Sci. 2006, 71, 753-760. [PubMed]

44. Forney, D.R.; Foy, C.L.; Wolf, D.D. Weed suppression in no-till alfalfa (Medicago sativa) by prior cropping of summer-annual forage grasses. Weed Sci. 1985, 33, 490-497. [CrossRef]

45. Petit, H.V.; Pesant, A.R.; Barnett, G.M.; Mason, W.N.; Dionne, J.L. Quality and morphological characteristics of alfalfa as affected by soil moisture, $\mathrm{pH}$ and phosphorus fertilization. Can. J. Plant Sci. 1992, 72, 147-162. [CrossRef]

46. Beck, L.; Marsalis, M.; Lauriault, L. Managing Weeds in Alfalfa. Guide A-325; Cooperative Extension Service: Las Cruses, NM, USA, 2017; Available online: https://aces.nmsu.edu/pubs/_a/A325.pdf (accessed on 7 March 2021).

47. Travlos, I.; Gazoulis, I.; Kanatas, P.; Tsekoura, A.; Zannopoulos, S.; Papastylianou, P. Key factors affecting weed seeds' germination, weed emergence, and their possible role for the efficacy of false seedbed technique as weed management practice. Front. Agron. 2020, 2, 1. [CrossRef]

48. Grewal, H.S. Fertilizer management for higher productivity of established lucerne pasture. J. Agric. Res. 2010, 53, 303-314.

49. Weaver, S.E.; Tan, C.S.; Brain, P. Effect of temperature and soil moisture on time of emergence of tomatoes and four weed species. Can. J. Plant Sci. 1988, 68, 877-886. [CrossRef]

50. Fischer, D.W.; Harvey, R.G.; Bauman, T.T.; Phillips, S.; Hart, S.E.; Johnson, G.A.; Kells, J.J.; Westra, P.; Lindquist, J. Common lambsquarters (Chenopodium album) interference with corn across the northcentral United States. Weed Sci. 2004, 52, 1034-1038. [CrossRef]

51. Taab, A.; Andersson, L. Seed dormancy dynamics and germination characteristics of Solanum nigrum. Weed Res. 2009, 49, 490-498. [CrossRef]

52. Baskin, J.M.; Baskin, C.C. Role of temperature in the germination ecology of three summer annual weeds. Oecologia 1977, 30, 377-382. [CrossRef]

53. Curran, W.S.; Ryan, M.R.; Myers, M.W.; Adler, P.R. Effects of seeding date and weed control on switchgrass establishment. Weed Technol. 2012, 26, 248-255. [CrossRef]

54. Brosnan, J.T.; Breeden, G.K.; Zobel, J.M.; Patton, A.J.; Law, Q.D. Nonchemical annual bluegrass (Poa annua) management in zoysiagrass via fraise mowing. Weed Technol. 2020, 34, 482-488. [CrossRef] 